\title{
EFISIENSI LUAS PANEN PADI DI PROVINSI SULAWESI SELATAN TAHUN 2018
}

\author{
(Efficiency of Rice Harvest Area in South Sulawesi Province in 2018)
}

Ugiana Ramdhani

Badan Pusat Statistik, Kabupaten Bone, Indonesia

Email: ramdhaniugiana@gmail.com

Article Submitted : 24-11-2018

Article Accepted : 25-01-2019

\begin{abstract}
The food crop subsectors is one of the centers of attention in national development. Various efforts have been made to increase rice production, both through extensification of paddy fields and intensification of planting. South Sulawesi is one of the largest rice production centers in Indonesia in 2018 and deserves special attention in this regard. To be able to find out the right programs and efforts to increase rice production, information is needed regarding the potential and land use in the province of South Sulawesi. The study was conducted with mixed methods (qualitative and quantitative using data from the rice harvest area of South Sulawesi Province in 2018) which was simply analyzed using descriptive statistics to describe the results of data processing from the Central Bureau of Statistics, followed by in-depth interviews with six people to capture phenomenon that occurs in South Sulawesi. The efficiency of harvested area in South Sulawesi is currently 176.50 that caused by there is still land that is only harvested once a year or three times in two years so efforts need to be made to increase the efficiency of harvesting area through intensification of cropping.
\end{abstract}

Keywords: harvest area, paddy, efficiency

\section{PENDAHULUAN}

Sektor pertanian merupakan salah satu sektor yang menjadi pusat perhatian dalam pembangunan nasional, khususnya yang berhubungan dengan pengelolaan dan pemanfaatan hasil-hasil strategis terutama yang menyangkut komoditas pangan (Isbah, U., \& Iyan, R.Y, 2016).

Beras yang merupakan hasil olahan dari tanaman padi adalah komoditas pangan utama masyarakat Indonesia, hampir seluruh penduduk di negara ini mengkonsumsi beras setiap harinya. Hal ini menyebabkan komoditas beras memiliki nilai yang sangat strategis (Rohman, A \& Maharani, A.D, 2017).

Berbagai macam upaya telah dilakukan untuk meningkatkan produksi padi.
Salah satu strategi utama yang ditempuh dalam upaya peningkatan produksi padi tersebut yaitu intensifikasi melalui peningkatan hasil per satuan luas maupun peningkatan intensitas tanam dari 1 kali menjadi 2 dan 3 kali tanam setiap tahun (Suwarno, 2010).

Menurut Ishaq, M. et al (2016) faktor yang paling berpengaruh terhadap produksi padi adalah luas panen. Jika luas tanam berbanding lurus dengan luas panen maka intensifikasi dengan meningkatkan intensitas tanam akan meningkatkan efisiensi luas panen, sehingga dengan mengetahui tingkat efisiensi luas panen serta apa yang mempengaruhinya dapat pula diketahui upaya apa yang dapat ditempuh untuk meningkatkannya. 
Efisiensi menurut Mulyamah (1987) adalah suatu ukuran dalam membandingkan rencana penggunaan masukan dengan penggunaan yang direalisasikan atau perkataan lain penggunaan yang sebenarnya. Jadi efisiensi pemanfaatan lahan pertanian dapat diartikan sebagai realisasi penggunaan lahan terhadap luas baku lahan yang tersedia. Semakin tinggi nilai efisiensi menunjukkan pemanfaatan lahan yang maksimal.

Sulawesi Selatan adalah salah satu sentra produksi padi terbesar dan memiliki luas panen tertinggi keempat nasional (BPS, 2018). Hasil analisa Susilowati, S.H. (2017) bahkan mengungkapkan bahwa Sulawesi Selatan menjadi produsen sekaligus pemasok beras utama bagi provinsi dengan keadaan defisit beras. Terkait dengan hal tersebut, Sulawesi Selatan perlu mendapat perhatian dalam hal efisiensi luas panen sehingga dapat memaksimalkan potensi di Sulawesi Selatan.

Belum banyak penelitian serupa yang meneliti mengenai efisiensi luas panen sawah untuk meningkatkan produksi padi. Penelitian terdahulu mengungkapkan bahwa faktor yang paling mempengaruhi produksi padi adalah luas panen (Ishak, M. et al, 2016), sehingga penting untuk mengetahui efisiensi luas panen yang ada di provinsi Sulawesi Selatan.

Berdasarkan latar belakang diatas, maka rumusan masalah dalam penelitian ini adalah: bagaimana efisiensi luas panen padi di Sulawesi Selatan?, faktor apa yang dapat mempengaruhi efisiensi luas panen padi di Sulawesi Selatan serta bagaimana persebaran lahan sawah di Sulawesi Selatan?

\section{METODE PENELITIAN}

Penelitian ini merupakan penelitian menggunakan metode kuantitatif dan kualitatif yang dianalisis secara sederhana menggunakan statistik deskriptif yang dipadukan dengan in-depth interview kepada kelompok responden yang mengetahui atau mengerti fenomena yang terjadi di wilayah provinsi Sulawesi Selatan. Sumber data yang digunakan adalah data BPS mengenai luas lahan dan luas panen tanaman padi tahun 2018 hasil Survei Kerangka Area (KSA) Tahun 2018.

\section{HASIL DAN PEMBAHASAN}

Provinsi Sulawesi Selatan terdiri dari 24 kabupaten/kota yang dalam penelitian ini dikelompokkan menjadi lima wilayah/region, yaitu:

- Ajatappareng : Kab. Pangkajene dan Kepulauan, Barru, Enrekang, Pinrang dan Kota Pare-pare.

- Bosowasi : Kab. Bone, Soppeng, Wajo dan Sidenreng Rappang.

- Mamminasata : Kota Makassar, Kab. Maros, Gowa dan Takalar.

- Luwu Raya : Kab. Luwu, Luwu Timur, Luwu Utara, Tana Toraja, Toraja Utara dan Kota Palopo.

- Selatan-selatan : Kab. Selayar, Bulukumba, Bantaeng, Jeneponto dan Sinjai. 


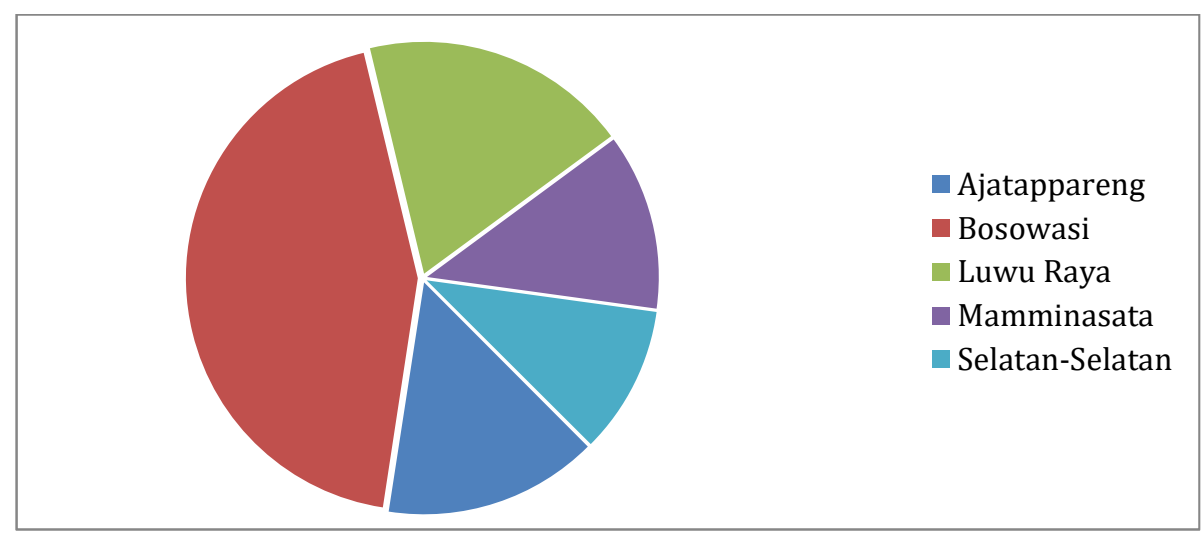

Grafik 1. Luas Lahan Sawah menurut Wilayah/Region di Proinsi Sulawesi Selatan (Ha)

Grafik 1 di atas menunjukkan proporsi luas baku lahan sawah untuk masing-masing wilayah di provinsi Sulawesi Selatan terhadap total luas baku lahan sawah. Wilayah Bosowasi mendominasi luas lahan sawah di Sulawesi
Selatan sebesar 43.82 persen, sedangkan wilayah Selatan-selatan merupakan wilayah dengan persentase luas lahan terkecil yaitu 10.32 persen.

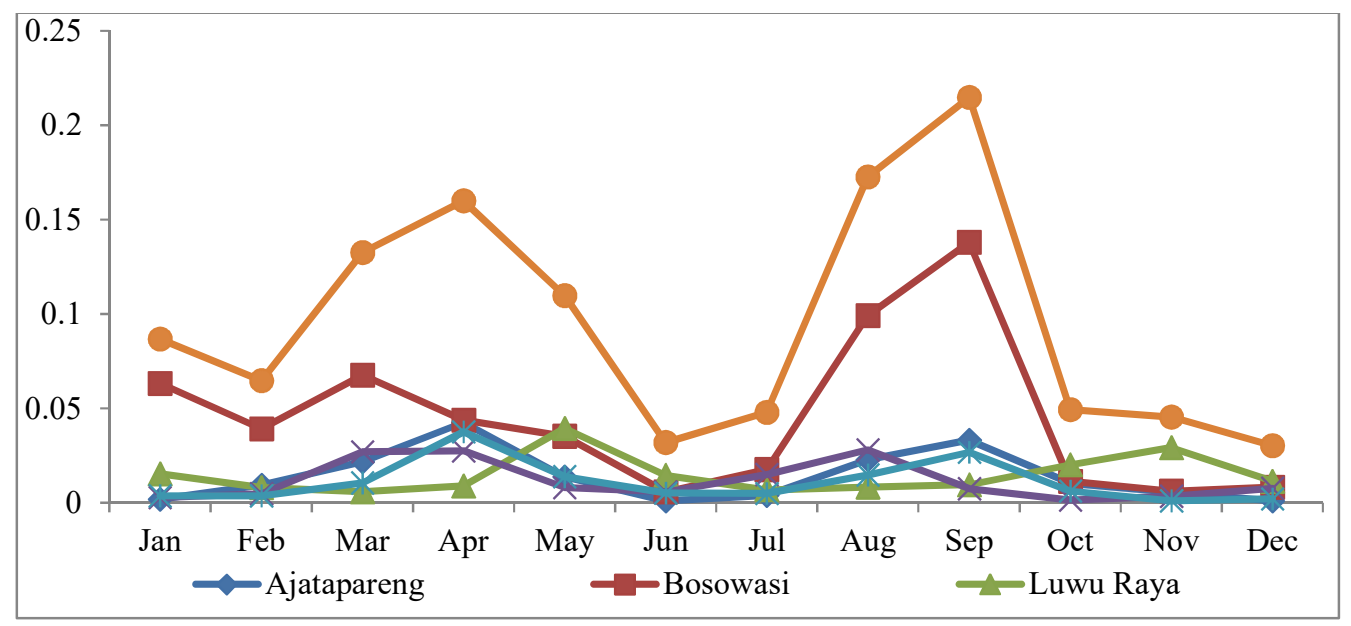

Grafik 2. Luas Panen Padi menurut Wilayah di Provinsi Sulawesi Selatan Tahun 2018

Pada grafik diatas digambarkan luas panen di masing-masing wilayah Sulawesi Selatan setiap bulannya. Seperti yang terlihat pada grafik tersebut, panen dengan luasan terbesar terjadi pada bulan September, Agustus dan April. Luas panen di wilayah Luwu Raya memiliki pola yang berbeda jika dibandingkan dengan wilayah lain. Seperti ketika pada bulan Maret ketika produksi pada umumnya meningkat tapi Luwu Raya menunjukkan penurunan luas panen, dan justru meningkat di bulan April saat wilayah lainnya mengalami penurunan luas panen. 


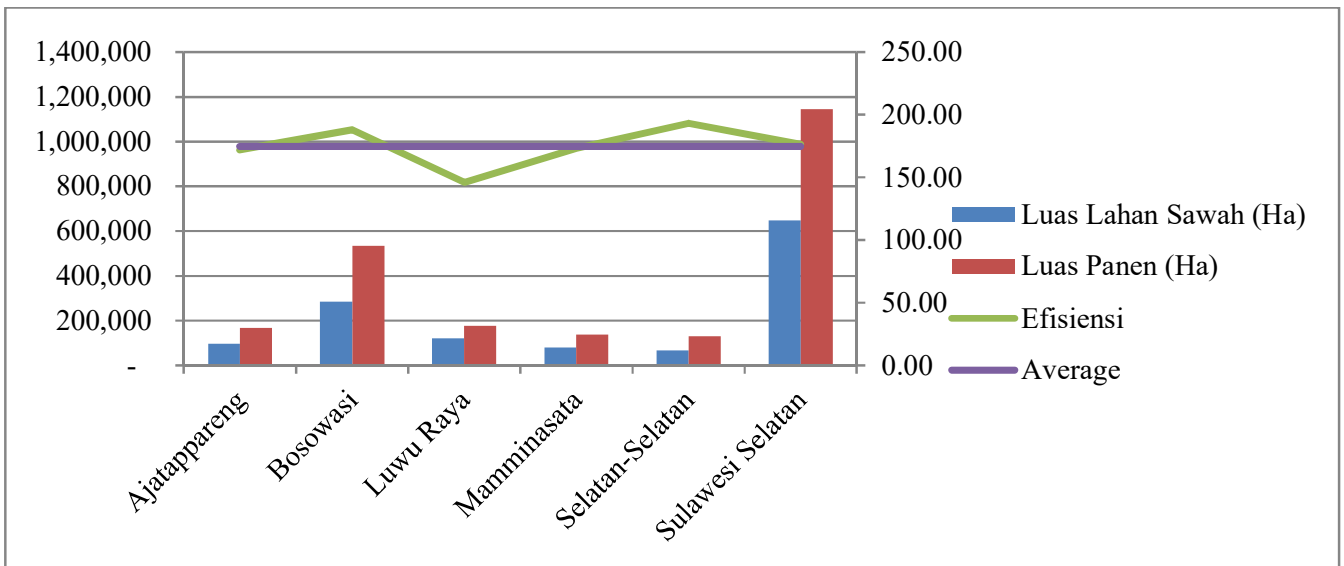

Grafik 3. Efisiensi Luas Panen Padi terhadap Luas Lahan Sawah di Provinsi Sulawesi Selatan, 2018

Dari grafik 3 tersebut kita juga dapat melihat bahwa tingkat efisiensi luas panen padi terhadap luas lahan sawah masih menunjukkan angka dibawah 200, hal ini bisa disebabkan karena masih banyak lahan di Sulawesi Selatan yang dipanen hanya satu kali dalam setahun atau tiga kali dalam dua tahun.

Meski memiliki luas lahan sawah terkecil, pada kenyataannya efisiensi luas panen di wilayah Selatan-selatan adalah yang terbesar yaitu 193.21, lebih tinggi jika dibandingkan dengan Bosowasi sebagai sentra produksi padi di Sulawesi Selatan dengan efisiensi 187.97. Selain itu, wilayah Luwu Raya yang merupakan wilayah dengan luas lahan terbesar kedua setelah Bosowasi, justru menunjukkan efisiensi terkecil dengan nilai 145.95, hal ini menunjukkan efisiensi pemanfaatan lahan yang sangat minim.

Berdasarkan hasil in-depth interview, 3 dari 6 responden mengungkapkan bahwa salah satu penyebab utama rendahnya efisiensi lahan sawah di wilayah Luwu Raya karena sebagian besar lahan sawah hanya ditanami satu kali dalam setahun. Penyebab lainnya adalah kondisi topografi di wilayah tersebut yang berupa pegunungan, serta kejadian banjir yang melanda lahan sawah di beberapa tempat.

Kondisi ini tentu tidak baik jika terus berlangsung lama. Sebagai salah satu lumbung padi nasional (Herniwati dan Kadir, S., 2009), provinsi Sulawesi Selatan diharapkan mampu menyumbang surplus beras untuk kebutuhan pangan nasional. Untuk menghasilkan produksi padi yang tinggi, faktor terbesar yang mempengaruhi adalah luas panen padi (Ishaq, M. et al, 2016).

Sebuah terobosan yang dilakukan oleh Badan Litbang Pertanian dalam upaya meningkatkan produksi padi adalah melalui peningkatan indeks pertanaman yang dikenal dengan IP Padi 400 (BB Padi, 2009). Salah satu wilayah yang memenuhi syarat untuk sebagai lokasi pengembangan IP 400 adalah provinsi Sulawesi Selatan, dengan kondisi waktu yang tersedia untuk pertanaman harus sama atau kurang dari 12 bulan untuk empat musim tanam atau 3 bulan/musim dan tersedia air sepanjang tahun (Supriatna, A. 2012).

Jika luas panen diasumsikan sama dengan luas tanam, maka diharapkan target luas panen untuk meningkatkan produksi bisa dicapai melalui upaya tersebut, efisiensi luas panen mencapai angka 400.

\section{KESIMPULAN DAN SARAN}

Efisiensi luas panen menjadi salah satu penentu produksi padi. Tingginya rendahnya produksi padi sangat bergantung pada besar kecilnya nilai efisiensi luas panen lahan di wilayah tersebut. Sulawesi Selatan 
yang memiliki wilayah persawahan yang luas menjadi salah satu tumpuan dalam pemenuhan kebutuhan pangan nasional yang meningkat seiring pertambahan jumlah penduduk. Namun kenyataan yang terjadi pada saat ini, efisiensi luas panen masih jauh dari harapan. Dibutuhkan upaya untuk meningkatkan nilai efisiensi penggunaan lahan sehingga produksi padi dapat ditingkatkan.

Diperlukan penelitian lebih lanjut dan mendalam mengenai penyebab rendahnya efisiensi luas panen atau pemanfaatan lahan agar dapat menemukan cara atau upaya untuk meningkatkatkan efisiensi mengingat potensi yang ada serta kontribusi yang dapat diberikan dalam memenuhi kebutuhan pangan nasional.

\section{DAFTAR PUSTAKA}

Badan Pusat Statistik. 2018. Luas Panen dan Produksi Padi di Indonesia 2018 : 1

BB Padi. 2009. Pedoman umum peningkatan IP padi 400. Peningkatan produksi padi melalui pelaksanaan IP padi 400. Balai Besar Penelitian Tanaman padi. Badan Litbang Pertanian : 48

Herniwati Dan Kadir, S. 2009. Potensi Iklim, Sumber Daya Lahan Dan Pola Tanam Di Sulawesi Selatan. Balai Pengkajian Teknologi Pertanian Sulawesi Selatan. Prosiding Seminar Nasional Serealia 2 : 218

Isbah, U., \& Iyan, R.Y. 2016. Analisis Peran Sektor Pertanian dalam Perekonomian dan Kesempatan Kerja di Provinsi Riau. Jurnal Sosial Ekonomi Pembangunan (hlm. 45).
Ishaq, M., Rumiati, A.T., dan Permatasari, E.O. 2016. Analisis Faktor-Faktor yang Mempengaruhi Produksi Padi di Provinsi Jawa Timur Menggunakan Regresi Semiparametrik Spline. Jurnal Sains dan Seni ITS Vol. 5 No. $2: 425$

Mulyamah. 1987. Manajemen Perubahan. Jakarta: Yudhistira : 3

Rohman, A \& Maharani, A.D,. 2017. Proyeksi Kebutuhan Konsumsi Pangan Beras Di Daerah Istimewa Yogyakarta. Jurnal Caraka Tani: Journal of Sustainable Agriculture. Universitas Sebelas Maret : 29

Supriatna, A. 2012. Meningkatkan Indeks Pertanaman Padi Sawah Menuju Ip Padi 400. Jurnal Agrin Vol. 16, No. 1, April 2012:2

Susilowati, S.H. 2017. Perdagangan Antarpulau Beras Di Provinsi Sulawesi Selatan. Jurnal Analisis Kebijakan Pertanian, Vol. 15 No. 1, Juni 2017: 1941

Suwarno, 2010. Meningkatkan Produksi Padi Menuju Ketahanan Pangan Yang Lestari. Jurnal Pangan, Vol. 19 No. 3 September 2010: 235 